\title{
Integrated Ozone and Anoxic-Aerobic Activated Sludge Reactor for Endek (Balinese Textile) Wastewater Treatment
}

\author{
I Wayan Koko Suryawan ${ }^{1 *}$, Mia Juliana Siregar², Gita Prajati ${ }^{1}$, Anshah Silmi Afifah $^{1}$ \\ 1 Environmental Engineering Department, Universal University, Batam, Indonesia \\ 2 Industrial Engineering Department, Universal University, Batam, Indonesia \\ * Corresponding author's e-mail: iwayankokosuryawan@uvers.ac.id
}

\begin{abstract}
The endek industry produces low-biodegradable wastewater, which is very difficult to treat using the biological methods. For this reason, this study was aimed at improving the quality of wastewater for endek textile wastewater using the combination of ozone oxidation process as pretreatment and anoxic-aerobic activated sludge. The ozone reactor volume amounted to $3 \mathrm{~L}$ and the applied ozone dose equaled $0.05 \mathrm{mg} / \mathrm{minute}$. The BOD/COD of endek wastewater increased to 0.38 after ozone treatment and the application of anoxic-aerobic activated sludge treatment. The anoxic-aerobic experiments were conducted in batch process and consisted of activated sludge. Conventional anoxic-aerobic treatment can reach color and COD removal of $30 \%$ and $32 \%$, respectively, without pre-treatment. The ozone pretreatment can increase color and COD removal up to $76.6 \%$ and $86.9 \%$, respectively. On the basis of the effluent standards of textile wastewater quality, $\mathrm{COD}, \mathrm{BOD}_{5}$, and total ammonia $\left(\mathrm{NH}_{3}-\mathrm{N}\right) \mathrm{pa}-$ rameters have met the quality standards.
\end{abstract}

Keywords: low-biodegradable wastewater, ozone oxidation process, anoxic-aerobic activated sludge

\section{INTRODUCTION}

Endek is an ethical Balinese weaving known for national and international tourists. Endek is used as traditional clothing and also widely used for producing school and office uniforms. The endek woven fabric manufacturing uses dyes in the form of synthetic dyes, wax, and natural dyes. In order to produce endek woven fabric, it takes several processes such as the design process of motifs, binding of motifs, dyeing, and weaving. Dyeing is the main source of wastewater, which produces acids, bases, COD, BOD, suspended solids and chemicals. The dyeing process contributes primarily to the amount of organic matter in textile wastewater (Sarayu and Sandhya 2012). The dyes in water can limit the amount of penetrated light, as well as reducing photosynthetic activity. The textile wastewater contains multiple components of dyes and various organic compounds. Dyes are complex compounds that are diffucult to treat by conventional wastewater treatment plan.
Conventional textile wastewater treatment can be carried out chemically, physically, biologically or by employing a combination thereof. Individual treatment processes are not enough to degrade the dye from wastewater. Biological process cannot remove dyes because of their inorganic form and toxicity to the microorganisms used in process (Gosavi and Sharma 2013). Therefore, the treatment of wastewater contaminated with color has an important role in preventing environmental pollution (Saravanan, et al. 2013). The application of effective with low cost and high efficiency technology is very important. Dyes cannot be treated with aerobic biodegradation and cannot be easily processed using conventional biological treatment (Dehghani, et al. 2015). In the case of endek textile wastewater, it has a fairly low BOD/ $\mathrm{COD}$ ratio making it difficult to apply biological treatment. In order to increase the value of BOD/ $\mathrm{COD}$, the physicochemical pre-treatment process using ozone can be applied (Suryawan, Helmy and Notodarmojo, 2018; Bilinska, Gmurek and 
Ledakowicz, 2016; Malik, et al. 2018). Ozone can increase the value of biodegradability and improve processing efficiency (Pratiwi, Notodarmojo and Helmy 2018).

One common biological treatment used in wastewater treatment is activated sludge. Generally, anaerobic textile wastewater treatment focuses on color removal, while aerobic treatment deals with the removal of organic matter (Paździor, Bilińska and Ledakowicz 2018). The advantage of using activated sludge in aerobic treatment is the use of monooxygenase and dioxygenase enzymes to increase the incorporation of oxygen into organic aromatic rings to ring fission (Madigan, Martinko and Parker 2003). Biological treatment with activated sludge systems can remove $90 \%$ of COD and color but still cannot meet the standard requirements for wastewater quality (Paździor, Bilińska and Ledakowicz 2018). Generally, textile wastewater treatment only pays attention to the removal of colors and organic material, regardless of nitrogen removal that is also a major component in algae blooms. Under the existing conditions, the Endek wastewater treatment still uses the conventional activated sludge method. However, the result do not qualify to the quality standard of wastewater textile.

Improving the quality of effluent from endek wastewater prevents algae blooms. The industry must carry out efficient wastewater treatment, to ensure safe discharge into water bodies. The endek industry employs wastewater treatment using biological processes but the quality of effluent still does not meet the quality standards.
In order to improve the quality of effluent from textile wastewater, the industry can add preliminary treatment using ozone. According to the above-mentioned problem, the purpose of this study was to determine the effectiveness of ozone as a preliminary treatment in the endek wastewater treatment.

\section{MATERIALS AND METHOD}

\section{Experimental reactor}

The ozone reactor and activated sludge used in this study has a volume of $3 \mathrm{~L}$. The ozone reactor was run in batch system. The air containing ozone was produced using an ozone generator. The ozone dose used in this study was 0.05 $\mathrm{g} /$ minute. The remaining ozone flowed into KI solution (see Fig. 1) to avoid direct contact with human.

The activated sludge collected from the excess of biological tank sludge at the sewage treatment plant in Denpasar. The activated sludge treatment was carried out in two phases, anoxic and aerobic. The treatment process was maintained under anoxic conditions so that dissolved oxygen $0.3-0.7$ $\mathrm{mg} / \mathrm{L}$ (Suryawan, Afifah, and Prajati, 2019) using $\mathrm{N}_{2}$ tube. After the removal of COD or color was constant, the treatment continued to the aerobic process. The air was transferred into the activated sludge reactor until oxygen met the criteria for an aerobic process $(\mathrm{DO}>4 \mathrm{mg} / \mathrm{L})($ Djenar and Soeswanto, 2005).

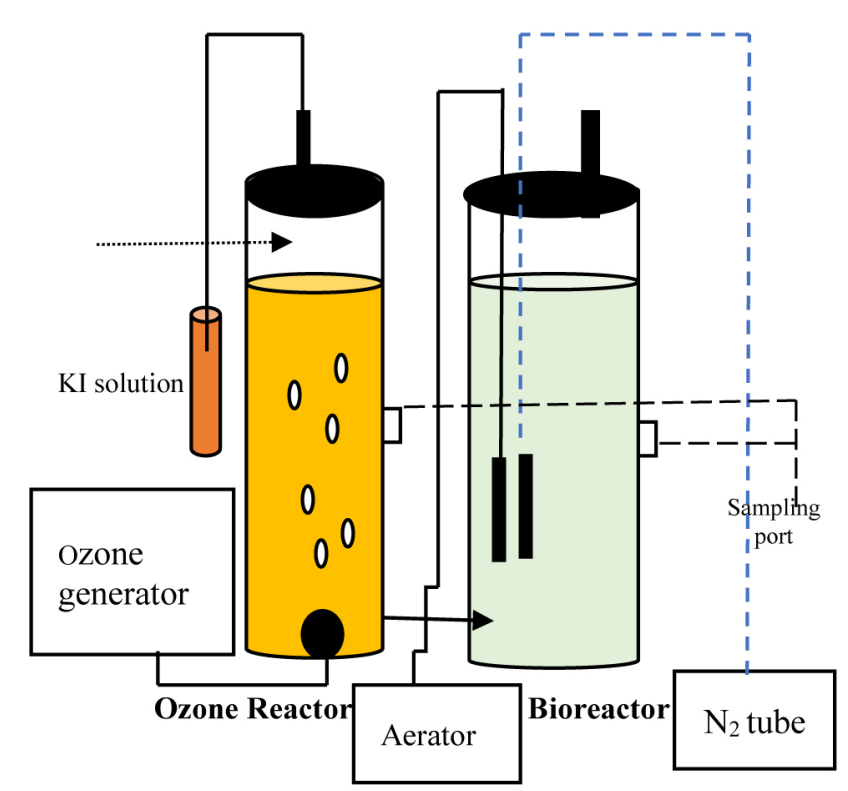

Fig. 1. Integration of the reactor used in for endek wastewater treatment 


\section{Measured parameters}

The wastewater sample was taken from the sampling port with a volume of $25 \mathrm{~mL}$. The parameter measurements were carried out for the characteristics of color and organic matter. Color of wastewater measured (at $\lambda_{\max } 450-465 \mathrm{~nm}$ wavelengths), according to APHA Pt-Co (platinum-cobalt) unit. $\mathrm{COD}$ and $\mathrm{BOD}_{5}$ values was measured based on standard methods (APHA/ AWWA/WPCF, 1998). The $\mathrm{NH}_{3}-\mathrm{N}$ in the endek wastewater can be determined either colorimetrically with the phenate method (APHA/AWWA/ WPCF, 1998). MLVSS in biological treatment measured in a certain time. VSS can represent the biomass concentration referred from APHA/ AWWA/WPCF, (1998).

\section{RESULTS}

\section{Pre-treatment with ozone}

On the basis of the Pt-Co unit, the color that can be removed in 60 minutes was around $44.5 \%$ (Fig. 2). The removal of COD in textile wastewater was equal to $395 \mathrm{mg} / \mathrm{L}$. The initial $\mathrm{BOD}_{5} / \mathrm{COD}$ in endek wastewater showed a low biodegradable value of 0.25 , which increased to 0.38 after ozone pre-treatment. In turn, ammonia value in wastewater after ozone can be removed up to $23.8 \%$.

\section{Anoxic-Aerobic activated sludge process}

Endek wastewater treatment was carried out on two steps because it depends on the sludge retention time (SRT). Anoxic treatment with a SRT lasted for 21 days (Henze et al., 2002) and the aerobic treatment with SRT took 9 days (Franca et al., 2017). The results of pretreatment with ozone pretreatment showed more optimal results for $\mathrm{COD}$ and color parameters. Figure 3 presents the quality of anoxic-aerobic wastewater treatment with a retention time of 30 days. The degradation process can be seen by using spectra absorbance (Figure 4).

On the basis of the first psudo equation reaction, the specific biomass growth rate $(\mu)$ is obtained (equation 1). Where $d x / d t$ are rate of population growth and $X$ are growth rate of unity amount of biomass (unit $=1 / t$ ).

$$
\frac{d x}{d t}=\mu X
$$

The growth rate of biomass under anoxic conditions (0.0311/day) is lower than under aerobic conditions (0.109/day). This result is lower than the growth of microorganisms in wastewater with preliminary treatment with ozone (Table 1).

\section{Water quality standard}

Poor results were generated from endek wastewater treatment without ozone. The results of BOD and COD measurements in endek wastewater with ozone pre-treatment showed a considerable removal of $72.6 \%$ and $77.6 \%$, respectively,

Table 1. The bacterial growth rate for each activated sludge reactor

\begin{tabular}{|ccc|}
\hline Condition & $\begin{array}{c}\mu \text { without } \\
\text { pretreatment }\end{array}$ & $\begin{array}{c}\mu \text { with Ozone } \\
\text { pretreatment }\end{array}$ \\
\hline Anoxic & $0.0311 /$ day & $0.0315 /$ day \\
Aerobic & $0.1095 /$ day & $0.1379 /$ day \\
\hline
\end{tabular}

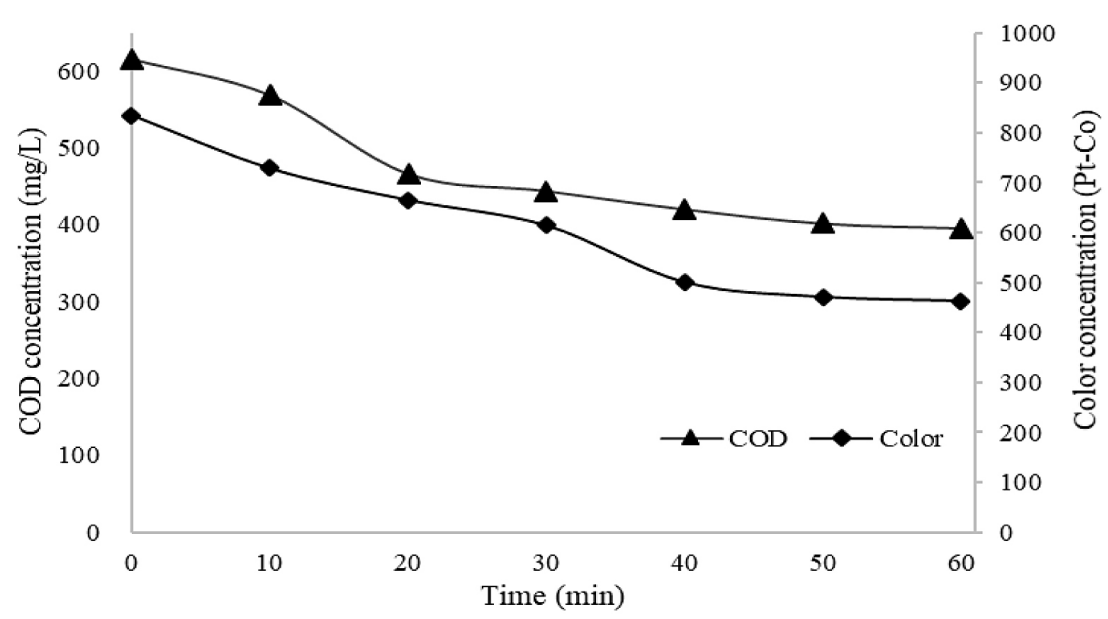

Fig. 2. Color and COD concentration of endek industrial wastewater during the ozone as pre-treatment 
Without ozone pre-treatment

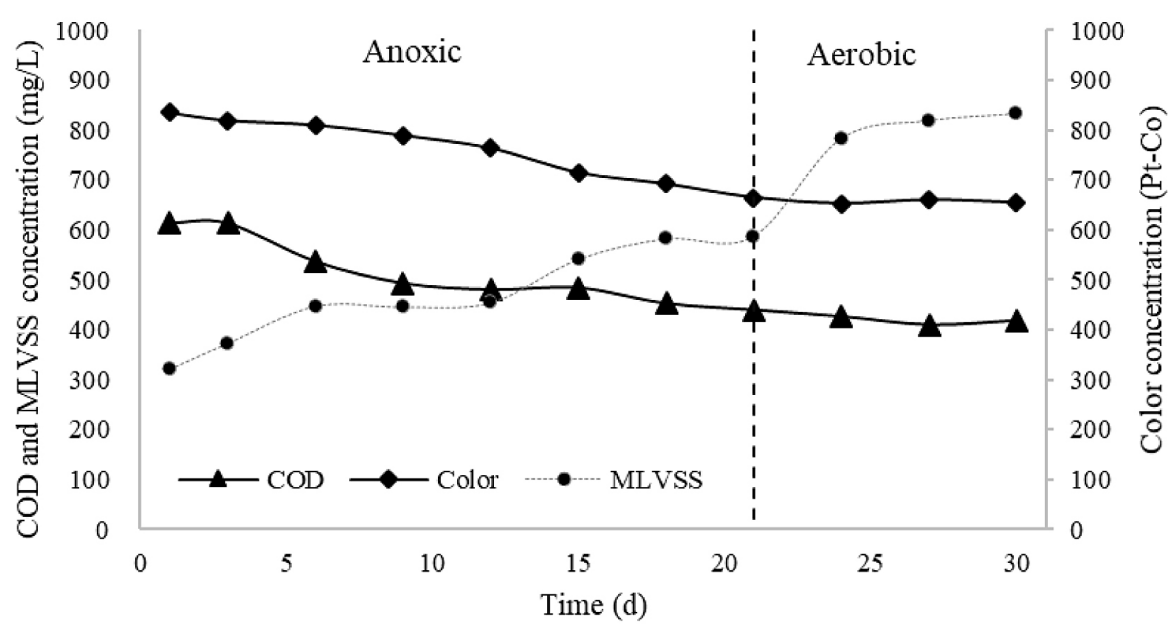

With ozone pre-treatment

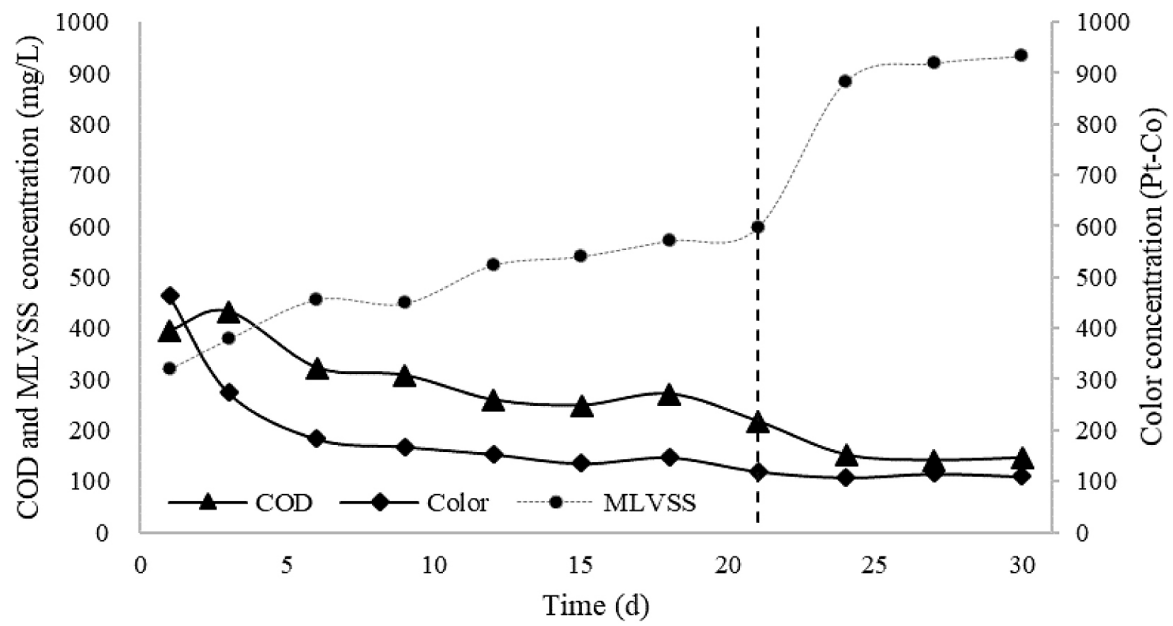

Fig. 3. COD, MLVSS, and color concentration of endek industrial wastewater during anoxic-aerobic activated sludge process

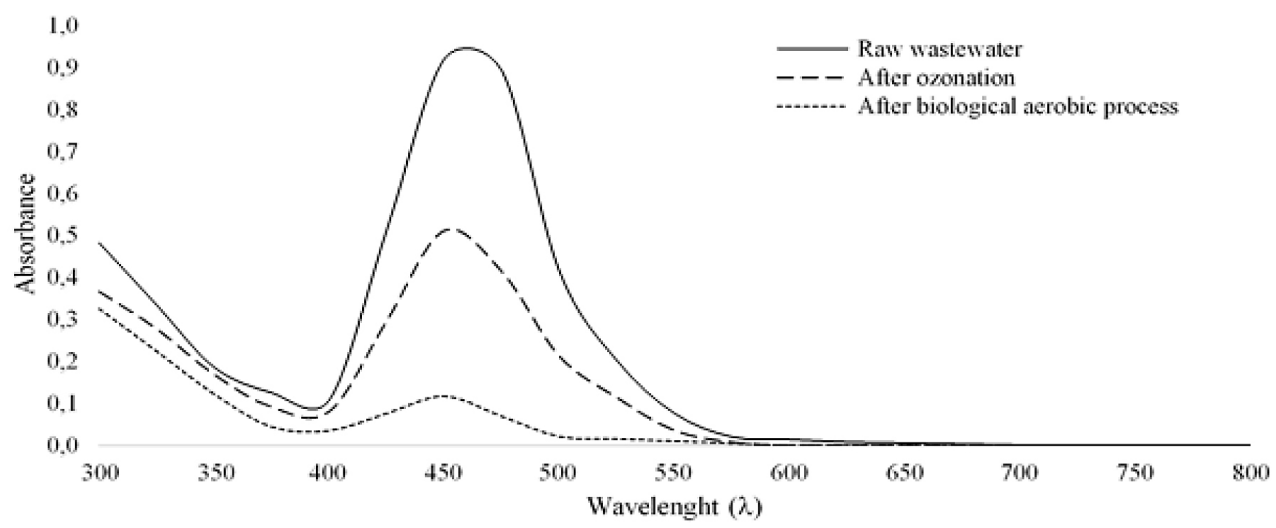

Fig. 4. The spectral absorbance in endek wastewater treatment.

the organic load on an activated sludge system had met the design criteria of $0.2-0.6 \mathrm{~g} \mathrm{BOD} / \mathrm{g}$ MLVSS/day ((Metcalf and Eddy, 2003).

The stability of COD removal percentage (32.1\%) was almost similar to the color concentration removal (21.5\%) for biological treatment without ozone pretreatment. Anoxic-aerobic treatment in artificial textile wastewater results in more than $95 \%$ of COD removal and this value is much greater than the treatment with real textile wastewater (Khehraa, et al. 2006, Smith, et al. 2006). The results of the study conducted by 
and already met the quality standard, except for European Regulations Union $\left(\mathrm{BOD}_{5}\right.$ dan $\left.\mathrm{COD}\right)$ dan Italy (Table 2).

\section{DISCUSSION}

\section{Pre-treatment with ozone}

According to Morali, Uzal and Yetis (2016), the best results that can be produced by the ozone process are reducing color by $86 \%$ and COD by $46 \%$. The decrease in COD occurred because ozone can break down the part of the chemical bonding and decompose the organic compounds in textile wastewater (Pratiwi, Notodarmojo and Helmy 2018). The value of the BOD/COD ratio enhancement in this study was low compared to Bilinska et al. (2016), who reported an increase from 0.2 to around 0.6 after treatment with ozone for 60 minutes (Bilinska, Gmurek and Ledakowicz 2016). Ammonia needs to be reduced because it can interfere the biological process; therefore ozone also plays a role in biological pre-treatment (Khuntia, Majumder and Ghosh 2012).

\section{Anoxic-Aerobic activated sludge process}

The initial characteristics of influents in anoxic-aerobic activated sludge treatment have COD to ammonia ratio 34.6. The small ratio of $\mathrm{C}$ : $\mathrm{N}$ inhibits the bacterial growth due to nitrogen limitations and if excessive, it can also cause acidification. The F/M ratio in initial wastewater was $0.46 \mathrm{~g}$ $\mathrm{BOD} / \mathrm{g}$ MLVSS/day. This parameter showed that
Smith, et al. (2006) showed the similarity of results in the removal yellow wastewater of $12 \%$.

Higher efficiency was obtained by ozone pretreatment, $63.15 \%$ in COD and $76.4 \%$ in color removal, respectively. Actually, this result is not good as in the case of MBBR (Moving Bed Biofilm Reactor) method, especially for color removal and COD (Pratiwi, Notodarmojo and Helmy 2018). However, ozone and anoxic-anaerob activated sludge method has advantage which is simpler to apply in reality (textile industry).

Ozone and biological aerated filter combinations also produce effluents that are less than 50 $\mathrm{mg} / \mathrm{L}$ (Wu, et al. 2016), where the results of this study only reached $14 \mathrm{mg} / \mathrm{L}$. Color removal in the study shows the similarity of results to ozone combination and biological activated carbon treatment with a value of $73 \%$ (Wang, et al. 2018).

- Indonesia (Regulation of the Minister of the Environment about Raw Wastewater Quality (Republic of Indonesia, Table XLII, 2014)

- European Union (Urban Wastewater Treatment Directive 91/271/EEC (European Commission - Environment, 1991)

- India (IS: 2490 Tolerance Limits for Industrial Effluents Discharged into Inland Surface Waters (Bureau of Indian Standards, 1981; and Environmental (Protection) Rules (India Ministry of Environment, Forest and Environment Change, 1986).)

- Thailand (Ministerial Notification No.2 (B.E. 2539, 1996) Issued in Accordance with the Factory Act (B.E. 2535, 1992), Industrial Effluent Standard (Thailand Ministry of Natural

Table 2. Comparison of quality standards for the endek wastewater treatment

\begin{tabular}{|c|c|c|c|c|c|c|c|c|c|c|c|c|c|}
\hline \multirow[b]{2}{*}{ No } & \multirow[b]{2}{*}{ Parameters } & \multicolumn{4}{|c|}{ Treatment process } & \multirow[b]{2}{*}{ Unit } & \multirow[b]{2}{*}{ Efficiency } & \multirow[b]{2}{*}{$\operatorname{Std}^{1}$} & \multirow[b]{2}{*}{$\operatorname{Std}^{2^{*}}$} & \multirow[b]{2}{*}{$\operatorname{Std}^{3^{*}}$} & \multirow[b]{2}{*}{$\operatorname{Std}^{4^{*}}$} & \multirow[b]{2}{*}{$\operatorname{Std}^{5^{*}}$} & \multirow[b]{2}{*}{$\operatorname{Std}^{6}$} \\
\hline & & $\begin{array}{c}\text { Raw } \\
\text { wastewater }\end{array}$ & $\begin{array}{l}\text { After } \\
\text { ozone }\end{array}$ & $\begin{array}{c}\text { After } \\
\text { anoxic } \\
\text { process } \\
\end{array}$ & $\begin{array}{c}\text { After } \\
\text { aerobic } \\
\text { process }\end{array}$ & & & & & & & & \\
\hline \multicolumn{14}{|c|}{ Without pretreatment } \\
\hline 1 & $\mathrm{BOD}_{5}$ & 151 & - & 132 & 108 & $\mathrm{mg} / \mathrm{L}$ & $28.6 \%$ & 60 & 25 & 100 & 60 & 50 & 40 \\
\hline 2 & COD & 615 & - & 440 & 418 & $\mathrm{mg} / \mathrm{L}$ & $32.0 \%$ & 150 & 125 & 250 & 400 & 200 & 160 \\
\hline 3 & $\mathrm{NH}_{3}-\mathrm{N}$ & 15.2 & - & 11.2 & 9.2 & $\mathrm{mg} / \mathrm{L}$ & $17.9 \%$ & 8 & - & 50 & - & 50 & 15 \\
\hline 4 & $\mathrm{pH}$ & 7.8 & - & 5.2 & 6.3 & - & - & $6-9$ & $6-9$ & $6-9$ & $6-9$ & $6-9$ & $6-9$ \\
\hline 5 & Color & 834.8 & - & 664.8 & 654.8 & Pt-Co & $30.0 \%$ & - & - & 400 & - & - & - \\
\hline \multicolumn{14}{|c|}{ With ozone pretreatment } \\
\hline 1 & $\mathrm{BOD}_{5}$ & 151 & 149 & 58 & 41 & $\mathrm{mg} / \mathrm{L}$ & $72.6 \%$ & 60 & 25 & 100 & 60 & 50 & 40 \\
\hline 2 & COD & 615 & 395 & 217 & 145 & $\mathrm{mg} / \mathrm{L}$ & $76.4 \%$ & 150 & 125 & 250 & 400 & 200 & 160 \\
\hline 3 & $\mathrm{NH}_{3}-\mathrm{N}$ & 15 & 11.4 & 6.9 & 4.1 & $\mathrm{mg} / \mathrm{L}$ & $73.0 \%$ & 8 & - & 50 & - & 50 & 15 \\
\hline 4 & $\mathrm{pH}$ & 7.8 & 7.6 & 5.4 & 6.6 & - & - & $6-9$ & $6-9$ & $6-9$ & $6-9$ & $6-9$ & $6-9$ \\
\hline 5 & Color & 834.8 & 463.0 & 119.4 & 109.4 & Pt-Co & $86.9 \%$ & - & - & 400 & - & - & - \\
\hline
\end{tabular}


Resources and Environment, Pollution Control Department, 1996)

- Bangladesh (The Environmental Conservation Rules (Environment Law Alliance Worldwide, 1997).

- Italy (Legislative Decree No. 152, Code on the Environment (Food and Agriculture Organization of the United Nations, 2006).

Color removal indicating the degradation process in endek wastewater treatment. According to Sastrawidana (2011), the decreasing of $\lambda_{\text {max }}$ indicates color degradation. The MVLSS concentration in wastewater indicates the growth of microorganisms. The increase in biodegradability greatly affects the efficiency and growth of biomass in activated sludge reactors.

\section{Water quality standard}

On the basis of several international standards, the results of endek wastewater treatment met the quality standards (Table 2) except for European Regulations Union $\left(\mathrm{BOD}_{5}\right.$ and $\left.\mathrm{COD}\right)$ and Italy $\left(\mathrm{BOD}_{5}\right)$. Besides, the $\mathrm{BOD}_{5}$ and COD ammonia value in wastewater can contribute a large amount organic pollution. The quality standard for ammonia in textile wastewater effluent is $8 \mathrm{mg} / \mathrm{L}$, high ammonia content also causes eutrophication in water. Therefore, in this study, the ammonia value was measured. The ozone pretreatment results are able to remove $73 \%$ of ammonia in endek wastewater (Table 2). Another study, ozone-based leachate treatment applications can increase the removal of ammonia to $300 \%$ within 60 minutes ( $\mathrm{Shu}$, et al. 2010). In order to improve the quality of effluent for water reuse, advanced treatment such as adsorption, and advanced oxidation processes (AOP) can be used (Suryawan, Afifah and Prajati 2018, Mondal and Bhagchandani 2016, Khamparia and Jaspal 2017, Khantae, Pons and Zahra 2009).

\section{CONCLUSION}

The pre-treatment of endek wastewater using ozone improved the $\mathrm{BOD}_{5} / \mathrm{COD}$ to 0.38 . It can remove color up to $44.5 \%$ and COD up to $35.8 \%$. After biological treatment using activated sludge, the quality of endek wastewater met the quality standard. The obtained values organic compounds were equal to $138 \mathrm{mg} / \mathrm{L} \mathrm{COD}$ and 41 $\mathrm{mg} / \mathrm{L} \mathrm{BOD}_{5}$. The results of wastewater treatment with conventional anoxic-aerobic technology only set $32 \%$ of COD and $28.6 \%$ of BOD removal. The wastewater treatment efficiency increased to $76.4 \%$ of $\mathrm{COD}$ and $72.6 \%$ of $\mathrm{BOD}_{5}$ by using ozone pre-treatment. Another parameter that can also be removed in this process was total ammonia, which reached $73 \%$ removal. The ozone pretreatment process for endek wastewater treatment can improve the quality of wastewater properly.

\section{REFERENCES}

1. Bilinska L., Gmurek M. Ledakowicz S. 2016. Comparison between industrial and simulated textile wastewater treatment by AOPS - biodegradability, toxicity and cost assessment. Chemical Engineering Journal, 306, 550-559.

2. Dehghani M., Nasseri S., Mahdavi P., Mahvi A., Naddafi K., Jahed G. 2015. Evaluation of acid 4092 dye solution toxicity after uv/zno mediated nanophotocatalysis process using daphnia magna bioassay. Journal of Color Science and Technology, 5, 285-292.

3. Djenar N.S., Soeswanto B. 2005. Penyerapan polutan logam besi ( $\mathrm{Fe}$ ) dengan memanfaatkan tanaman eceng gondok. Jurnal Fluida, 4, 35-40.

4. Franca R.D.G., Ortigueira J., Pinheiro H.M. Lourenço, N.D. 2017. Effect of SBR feeding strategy and feed composition on the stability of aerobic granular sludge in the treatment of a simulated textile wastewater. Water Science and Technology, 76, 1188-1195.

5. Gosavi V.D., Sharma S. 2013. A general review on various treatment methods for textile wastewater. Journal of Environmental Science, Computer Science and Engineering \& Technology, 3, 029-039.

6. Henze M., Aspegren H., Jansen J.C., Nielsen P.H., Lee N. 2002. Effect of solids retention time and wastewater characteristics on biological phosphorus removal. Water Science \& Technology, 45, 137-44.

7. Khamparia S., Jaspal D. 2017. Adsorption in combination with ozonation for the treatment of textile waste water: a critical review. Frontiers of Environmental Science \& Engineering, 11, 1-18.

8. Khantae A., Pons M., Zahra O. 2009. Photocatalic degradation of three azo dyes using immobilezed $\mathrm{TiO} 2$, nanoparticles on glass plates activated by UV light irradiation: influence of dye molocular structure. Journal Of Hazadous Material, 168, 451-457.

9. Khehraa M.S., Sainia H.S., Sharmaa D.K., Chadhaa B.S., Chimni S.S. 2006. Biodegradation of azo dye C.I. Acid Red 88 by an anoxic-aerobic sequential bioreactor. Dyes and Pigments, 70, 1-7. 
10. Khuntia S., Majumder S., Ghosh P. 2012. Removal of ammonia from warter by ozone microbubbles. Industrial and Engineering Chemistry Reseach 318-326.

11. Madigan M.T., Martinko J.M., arker J. 2003. Brock Biology of Microorganisms. New Jersey,: Prentice-Hall, Inc. ISBN: 01306627129780130662712 01304914709780130491473.

12. Malik S.N., Ghosh P.C., Vaidya A.N., Mudliar S.N. 2018. Ozone pretreatment of biomethanated distillery wastewater in a semi batch reactor: mapping pretreatment efficiency in terms of COD, color, toxicity and biohydrogen generation. Biofuels, 1-9.

13. Metcalf and Eddy. 2003. Wastewater Engineering Treatment and Reuse 4th Edition. McGraw Hill: New York.

14. Mondal S., Bhagchandani C. 2016. Textile waste water treatment by advanced oxidation processes. Journal on Advances in Engineering Technology and Science 2. 2455-3131.

15. Morali E., Uzal N., Yetis U. 2016. Ozonation pre and post-treatment of denim textile mill effluent: effect of cleaner production measures. Journal of Cleaner Production, 137, 1-9.

16. Paździor K., Bilińska L., Ledakowicz S. 2018. A review of the existing and emerging technologies in the combination of AOPs and biological processes in industrial textile wastewater treatment. Chemical Engineering Journal.

17. Pratiwi, R., Notodarmojo S., Helmy Q. 2018. Decolourization of remazol black- 5 textile dyes using moving bed bio-film reactor. IOP Conference Series: Earth and Environmental Science, 106, 012089.

18. Saravanan N., Kannadasan T, Basha C.A., Manivasagan V. 2013. Biosorption of Textile Dye Using Immobilized Bacterial (Pseudomonas aeruginosa) and Fungal (Phanerochate chrysosporium) Cells. American Journal of Environmental Sciences, 9, 377-387.

19. Sarayu, K., Sandhya S. 2012. Current technologies for biological treatment of textile wastewater-a review. Appl Biochem Biotechnol, 167, 646-661.

20. Sastrawidana, I.D.K. 2011. Studi perombakan zat warna tekstil remazol red rb secara aerob menggunakan bakteri enterobacter aerogenes yang di- isolasi dari lumpur limbah tekstil. Jurnal Kimia, 5, 117-124.

21. Shu L., Qunhui W., Xuedong Z., Qifei H., Peikun H. 2010. Improved Pretreatment (CoagulationFloatation and Ozonation) of Younger Landfill Leachate by Microbubbles. Water Environment Research, 82, 657-665.

22. Smith B., O’Neal G., Boyter H., Pisczek J. 2006. Decolorizing textile dye wastewater by anoxic/aerobic treatment. Journal of Chemical Technology \& Biotechnology 82. 16-24.

23. Suryawan I.W.K., Afifah A.S., G. Prajati. 2018. Adsorbsi warna metylen blue menggunakan powder dan granular activated carbon biji binjai (Mangifera caesia). JTERA (Jurnal Teknologi Rekayasa), 3, 211-218.

24. Suryawan I.W.K., Afifah A.S., Prajati G. 2019. Degradasi bahan organik dan pertumbuhan biomassa konsorsium pada air limbah olahan babi dengan lumpur aktif anoksik. Jurnal Teknik Kimia dan Lingkungan, 3. 20-26.

25. Suryawan, I.W.K., Helmy Q., Notodarmojo S. 2018. Textile wastewater treatment: colour and COD removal of reactive black-5 by ozonation. IOP Conf. Series: Earth and Environmental Science, 106, 1-6.

26. Wang W.-L., Cai Y.-Z, Hu H.-Y., Chen J., Wang J., Xue G., and Wu Q.-Y. 2018. Advanced treatment of bio-treated dyeing and finishing wastewater using ozone-biological activated carbon: a study on the synergistic effects. Chemical Engineering Journal, 359, 168-175.

27. Wu H., Wang S., Kong H., Liu T., and Xia M. 2007. Performance of combined process of anoxic baffled reactor-biological contact oxidation treating printing and dyeing wastewater. Bioresource Technology, 98, 1501-1504.

28. Wu Q., Li W.-T., Yu W.-H., Li Y., Li A.-M. 2016. Removal of fluorescent dissolved organic matter in biologically treated textile wastewater by ozonation-biological aerated filter. Journal of the Taiwan Institute of Chemical Engineers, 59, 359-364.

29. ZDHC. 2016. Textile Industry Wastewater Discharge Quality Standards. https:/www.roadmaptozero.com/fileadmin/pdf/WastewaterQualityGuidelineLitReview.pdf. 